\title{
InCENTIVES In Nigeria’s Food MANufacturing INDUSTRIES and their Impact on Output and Prices
}

\author{
Ndubisi I Nwokoma ${ }^{1}$ \\ Department of Economics, University of Lagos, Nigeria
}

\begin{abstract}
Since the inception of the Nigerian government economic reform programme in 1986, various incentives have been granted to the manufacturing sector, as a means of lifting the sector from the constant low level of performance and contribution to GDP. This paper sets out to find out how these various government incentives have impacted on manufacturing output - with specific focus on the food sub sector. By studying the operating profile of selected food-manufacturing companies, using the Pearson correlation analysis with relevant output, employment and price index variables, it was found that the benefits of these incentives appear not to have been passed on to the general public. It is thus recommended that bench-mark performance expectations be set for manufacturers as a pre-condition for granting incentives in subsequent dispensations.
\end{abstract}

JEL L66

\section{1 Introduction}

The Nigerian manufacturing sector has been a major beneficiary of government incentives since independence in 1960. This has been due to the poor state of the sector prior to independence when, for example, the share of manufacturing in gross domestic product GDP was only 5 per cent.

Hence, in the early years of independence, there were direct government investment and other government promotional measures such as income tax exemptions for pioneer industries, generous deprecation rates and a variety of tariff concessions (Olayide, 1975: 53). Over the years, there has been a continuing government interest in the sector to ensure that it increased its contribution to gross national output. In the 1970s, during the era of the import-dependent industrialization strategy, there was a relative decline in manufacturing production with little or no diversification in products and production processes as projected (Loto, 2001). The share of manufacturing in GDP was 9 per cent in 1970, 10 per cent in 1980, declining to 8 per cent in 1990 and 1998, showing the yet unstable state of the sector in contribution to gross output. There are many factors that are responsible for this. The question that arises is the extent to which various government efforts through granting of production concessions and incentives, among others, have helped (or otherwise) to assist the sector in enhancing stability of prices of manufactures as well as employment and gross output in the sector.

In this paper, an effort is made to investigate the state of affairs in selected quoted companies in the food and beverages segment of the manufacturing sector, in determining the impact of government incentives on standard of living of the Nigerian populace through the reduction in prices or creation of employment. In other words, have the incentives granted the food and beverages sub-sector of manufacturing benefited the Nigerian public in terms of lower factory-gate prices as well as increased output for consumption? That is the thrust of this paper.

Section 2 gives an overview of Nigeria's manufacturing sector, with special focus on the food, beverage and tobacco sub-sector. The incentive structure to the sector in the post-SAP era is highlighted in section 3 while the 
theoretical framework and analysis is presented in section 4 . Section $\mathrm{V}$ provides the conclusion.

\section{2 \\ Overview of the Nigerian manufacturing sector}

The manufacturing sector in Nigeria has had an insignificant impact on the economy to date. According to Adenikinju (1996: 342), the sector performed very poorly recording a low share in the Nigerian GDP of 8.1 per cent in 1990 and 10.7 per cent in 1985 , compared to an average value of 27 per cent in Latin American countries, 25 per cent in East Asia and 34 per cent in the Pacific. The performance of the sector is also unimpressive in terms of the growth rate and value added.

Between 1973 and 1982, Nigeria's industrial sector grew rapidly at 12 per cent growth rate due to buoyant oil revenues and heavy public investments which accounted for about twothirds of total investments in manufacturing during the period. (Agbelogode, 1999: 32-36). From Table 1 below, the index of production for the various years between 1990 and 2000 indicates that slight improvements were recorded in the manufacturing sub-sectors of brewing, paints, refined petroleum products and soaps \& detergents. In many others, such as sugar confectionaries, soft drinks, synthetic fabrics, vehicle assembly and cotton textiles, among others, declines were experienced in the sector. The graphical sketch of the index of industrial production for the various sub-sectors is shown in the appendix. The entire sector suffered from high production costs during this period due to the depreciation of the naira, which in itself, was done to stimulate exports. Overall, the industrial sector has been bedeviled by a series of problems manifested in low value added and general poor performance.

Table 1

Index of manufacturing production (base year $1985=100)(1990-2000)$

\begin{tabular}{|c|c|c|c|c|c|c|c|c|c|c|c|}
\hline Item & 1990 & 1991 & 1992 & 1993 & 1994 & 1995 & 1996 & 1997 & 1998 & 1999 & 2000 \\
\hline $\begin{array}{l}\text { Sugar con- } \\
\text { fectionery }\end{array}$ & 93.7 & 129.1 & 176.6 & 134.4 & 106.5 & 59.4 & 57.5 & 56.1 & 56.5 & 55.7 & 56.9 \\
\hline Soft drinks & 364.4 & 243.5 & 186.4 & 159.7 & 148.4 & 153.2 & 160.9 & 157.1 & 162.1 & 170.5 & 172.6 \\
\hline Brewing & 97.8 & 100.7 & 117.5 & 97.0 & 95.2 & 103.9 & 107.5 & 116.7 & 119.3 & 125.5 & 126.9 \\
\hline $\begin{array}{l}\text { Cotton } \\
\text { textiles }\end{array}$ & 118.0 & 147.5 & 150.2 & 106.4 & 92.1 & 89.6 & 102.1 & 103.3 & 94.5 & 91.8 & 90.8 \\
\hline $\begin{array}{l}\text { Synthetic } \\
\text { fabrics }\end{array}$ & 1501.6 & 1921.1 & 1970.5 & 1229.0 & 1066.9 & 803.1 & 815.6 & 742.7 & 708.4 & 703.7 & 774.7 \\
\hline Footwear & 45.8 & 85.9 & 92.0 & 88.0 & 59.8 & 42.6 & 52.0 & 49.9 & 45.6 & 45.6 & 44.7 \\
\hline Paints & 62.7 & 98.0 & 99.7 & 110.6 & 98.4 & 118.1 & 122.2 & 114.0 & 112.9 & 112.3 & 113.7 \\
\hline $\begin{array}{l}\text { Refined } \\
\text { petroleum }\end{array}$ & 108.8 & 116.0 & 113.7 & 112.6 & 110.9 & 117.9 & 131.4 & 129.3 & 121.8 & 124.8 & 124.3 \\
\hline Cement & 88.7 & 98.7 & 100.5 & 104.1 & 95.0 & 93.2 & 88.8 & 91.5 & 90.5 & 92.0 & 92.3 \\
\hline $\begin{array}{l}\text { Roofing } \\
\text { sheets }\end{array}$ & 79.6 & 57.9 & 41.2 & 39.3 & 30.8 & 37.8 & 29.6 & 28.6 & 29.1 & 28.0 & 28.0 \\
\hline $\begin{array}{l}\text { Vehicle } \\
\text { assembly }\end{array}$ & 24.1 & 17.1 & 18.3 & 18.9 & 17.4 & 11.7 & 14.2 & 13.6 & 13.4 & 15.8 & 15.6 \\
\hline $\begin{array}{l}\text { Soap \& } \\
\text { detergent }\end{array}$ & 153.0 & 153.9 & 153.9 & 164.0 & 152.6 & 167.6 & 183.3 & 193.3 & 185.3 & 209.7 & 213.4 \\
\hline Radio \& TV & 12.2 & 11.8 & 11.6 & 10.1 & 8.9 & 6.0 & 5.8 & 4.5 & 4.0 & 4.0 & 3.2 \\
\hline Total & 162.9 & 178.1 & 182.7 & 145.5 & 144.2 & 136.3 & 138.7 & 138.5 & 133.1 & 137.7 & 141.7 \\
\hline
\end{tabular}


These problems include over-dependence on imported raw-materials, breakdown of plant and machinery due to old age, lack of spare parts due to shortage of foreign exchange, high production costs, high tariff on utilities, especially electricity, high interest rates on lending and competition from imported goods (Agbelogode, 1999: 32-36). In view of this, in the 1990s, the level of capacity utilisation in Nigeria's industrial sector has recorded very low levels, as indicated in Table 2 below. From the table, the average capacity utilisation was quite low for the leather footwear, paper products and the saw milling sub-sectors of manufacturing while the beer and stout, paints and cement and cement products sub-sectors fared fairly over the twelve-year period. Capacity utilisation rate for the entire manufacturing sector fared worst in the 1994-1997 periods with values fluctuating around 30.4 over the period. This is reflected in the graphical sketch shown in the appendix.

The operators in the Nigerian manufacturing sector can be classified into three distinct categories (Adenikinju, 1996: 342-47). In the first place, there are the small to medium-sized firms, which are mostly privately owned and primarily Nigerian in shareholding. They are the most active group of firms in the sector given their geographical spread and low start-up capital. They mostly operate in the informal sector. Next to these are the medium to large scale private and public manufacturing groups. A number of firms in this category are subsidiaries of foreign companies. The last category is comprised of companies owned and managed by the government for the facilitation of its industrialisation process. The fertilizer, steel and petrochemical plants, among other government projects, are in this category. Also, as Adenikinju observed, four phases can be identified in the development of manufacturing in Nigeria. These are:

1. The pre-1970 era covering the period of import substitution industrialisation. The performance of the sector was relatively good since high growth rates were recorded with reasonable levels of capacity utilisation.

2. The 1970 - 1980 era covering the oil boom period and the era of indigenisation. Government participation in the sector was remarkable and very high value added values were recorded alongside high rates of capacity utilisation.

3. The 1982 - 1985 era covering the period of the crash of international crude oil prices. This led to the termination of many governments programmes in the 4th National Development Plan with a consequent negative impact on manufacturing activities.

4. The post 1986 era, when the government policy of structural adjustment was introduced, implying change in government industrialisation policy, relaxation of indigenisation as well as trade and payments liberalization, among others. This had some slight positive impact on the industry, particularly in enabling an easier access to the market for procuring foreign exchange for imported raw materials. 
Table 2

Nigeria's industrial capacity utilisation by sectors (1990-2001) (\%)

\begin{tabular}{|c|c|c|c|c|c|c|c|c|c|c|c|c|}
\hline Sub-sector & 1990 & 1991 & 1992 & 1993 & 1994 & 1995 & 1996 & 1997 & 1998 & 1999 & 2000 & 2001 \\
\hline $\begin{array}{l}\text { Meat \& } \\
\text { dairy prod. }\end{array}$ & 24.1 & 36.6 & 29.3 & 42.5 & 30.6 & 12.7 & 21.3 & 37.1 & 39.4 & 41.3 & 43.2 & 45.8 \\
\hline $\begin{array}{l}\text { Veg. \& } \\
\text { grain mill }\end{array}$ & 25.0 & 34.0 & 20.5 & 45.3 & 37.5 & 40.4 & 40.4 & 8.3 & 12.2 & 14.0 & 16.8 & 30.1 \\
\hline $\begin{array}{l}\text { Bakery } \\
\text { product }\end{array}$ & 42.3 & 57.2 & 32.2 & 55.1 & 25.9 & 19.1 & 25.9 & 0.0 & 14.5 & 15.3 & 30.1 & 42.9 \\
\hline $\begin{array}{l}\text { Sugar } \\
\text { cocoa } \\
\text { confection. }\end{array}$ & 42.6 & 47.5 & 35.5 & 45.6 & 18.7 & 18.3 & 27.8 & 35.5 & 30.8 & 32.0 & 31.0 & 35.6 \\
\hline $\begin{array}{l}\text { Misc. food } \\
\text { preparation }\end{array}$ & 35.8 & 58.7 & 50.5 & 43.5 & 31.6 & - & - & 52.8 & 35.6 & 38.2 & 39.2 & 42.5 \\
\hline Beer \& stout & 59.2 & 62.4 & - & 54.6 & 28.4 & 31.9 & 30.5 & 57.4 & 54.2 & 47.1 & 49.4 & 52.7 \\
\hline Soft drinks & 47.0 & 38.6 & 35.4 & 53.4 & 38.5 & 41.5 & 50.4 & 12.0 & 30.9 & 22.0 & 27.0 & 35.2 \\
\hline Textiles & 52.2 & 54.9 & 44.3 & 60.0 & 38.2 & 44.3 & 46.5 & 50.0 & 33.4 & 20.2 & 21.4 & 20.8 \\
\hline $\begin{array}{l}\text { Knitting } \\
\text { carpet \& rug }\end{array}$ & 23.1 & 35.3 & 38.2 & 56.4 & 36.8 & 31.2 & 43.8 & 51.0 & 31.8 & 36.6 & 35.8 & 37.8 \\
\hline Leather prod. & 53.0 & 52.2 & 51.2 & 55.3 & 25.6 & 27.6 & 29.1 & 44.0 & 38.7 & 39.2 & 37.9 & 37.9 \\
\hline $\begin{array}{l}\text { Leather } \\
\text { footwear }\end{array}$ & 33.5 & 38.2 & 52.5 & 48.3 & 25.7 & - & - & 0.0 & 28.2 & 22.4 & 23.1 & 22.9 \\
\hline Saw milling & - & - & - & 47.1 & 23.5 & 4.8 & 80.0 & 0.0 & 27.4 & 30.0 & 26.8 & 30.9 \\
\hline $\begin{array}{l}\text { Wood \& } \\
\text { cork prod. }\end{array}$ & 36.6 & 48.7 & 47.9 & 60.0 & 33.7 & 35.2 & 39.5 & 80.6 & 34.9 & 0.0 & 0.0 & 0.0 \\
\hline $\begin{array}{l}\text { Paper } \\
\text { manuf. \& } \\
\text { prod. }\end{array}$ & 34.1 & 44.5 & 25.2 & 45.2 & 27.3 & 35.4 & 29.0 & 30.3 & 27.9 & 27.0 & 25.1 & 28.1 \\
\hline $\begin{array}{l}\text { Printing \& } \\
\text { publishing }\end{array}$ & 44.2 & 54.5 & 35.0 & 50.6 & 28.4 & 37.8 & 43.8 & 0.0 & 32.6 & 35.3 & 38.0 & 45.6 \\
\hline $\begin{array}{l}\text { Basic } \\
\text { indust. } \\
\text { chemical }\end{array}$ & 60.5 & 38.6 & 32.0 & 40.9 & 30.2 & 49.1 & 55.1 & 50.5 & 31.6 & 28.0 & 30.4 & 33.4 \\
\hline Paints & 34.0 & 30.1 & 44.5 & 52.3 & 27.3 & 31.7 & 38.5 & 39.1 & 40.3 & 43.4 & 47.0 & 49.2 \\
\hline $\begin{array}{l}\text { Drugs \& } \\
\text { medicine }\end{array}$ & 44.1 & 45.6 & 34.9 & 55.0 & 35.6 & 39.9 & 36.4 & 35.1 & 16.6 & 36.1 & 38.6 & 40.8 \\
\hline $\begin{array}{l}\text { Soap \& } \\
\text { perfumes }\end{array}$ & 48.8 & 32.6 & 41.6 & 56.1 & 32.6 & 35.3 & 38.2 & 0.0 & 40.2 & 43.3 & 45.6 & 48.2 \\
\hline $\begin{array}{l}\text { Other chem. } \\
\& \text { petrol. } \\
\text { Prod. }\end{array}$ & 49.4 & 41.5 & 53.2 & 657 & 30.7 & 29.4 & 32.1 & 37.7 & 43.6 & 41.0 & 46.8 & 47.6 \\
\hline $\begin{array}{l}\text { Tyres \& } \\
\text { tubes }\end{array}$ & 57.2 & - & 41.6 & 52.6 & 30.9 & - & - & 0.0 & 30.1 & 30.5 & 31.8 & 32.8 \\
\hline $\begin{array}{l}\text { Plastic } \\
\text { products }\end{array}$ & 49.5 & 39.2 & 38.4 & 49.2 & 27.6 & 28.3 & 31.1 & 40.5 & 40.1 & 41.2 & 45.1 & 47.7 \\
\hline
\end{tabular}




\begin{tabular}{|l|c|c|c|c|c|c|c|c|c|c|c|c|}
\hline $\begin{array}{l}\text { Glass \& } \\
\text { glass } \\
\text { products }\end{array}$ & - & 32.3 & 25.2 & 45.6 & 30.4 & 33.0 & 30.4 & 40.5 & 32.0 & 41.0 & 42.3 & 44.9 \\
\hline $\begin{array}{l}\text { Cement \& } \\
\text { cement prod. }\end{array}$ & 46.3 & 33.2 & 44.3 & 63.5 & 33.1 & 35.6 & 33.5 & 0.0 & 46.6 & 48.5 & 49.1 & 48.8 \\
\hline $\begin{array}{l}\text { Basic metal } \\
\text { industries }\end{array}$ & 15.0 & - & 43.9 & 57.6 & 26.8 & 25.6 & 33.7 & 37.5 & 20.8 & 0.0 & 0.0 & 0.0 \\
\hline $\begin{array}{l}\text { Structural } \\
\text { metal prod. }\end{array}$ & 28.1 & 46.7 & 59.8 & 65.7 & 35.6 & 40.0 & 46.1 & 43.7 & 21.6 & 0.0 & 0.0 & 0.0 \\
\hline $\begin{array}{l}\text { Fabricated } \\
\text { metal prod. }\end{array}$ & 33.6 & 34.6 & 39.8 & 53.4 & 30.5 & 28.3 & 33.4 & 50.5 & 40.8 & 45.2 & 47.1 & 49.8 \\
\hline $\begin{array}{l}\text { Radio TV \& } \\
\text { comm. } \\
\text { eqpmt. }\end{array}$ & 42.3 & 34.6 & 18.2 & 57.4 & 30.4 & 29.8 & 38.7 & 35.2 & 35.9 & 33.4 & 36.7 & 35.6 \\
\hline $\begin{array}{l}\text { Motor } \\
\text { vehicle } \\
\text { assembly }\end{array}$ & 27.9 & 19.6 & 12.7 & 41.5 & 31.6 & 35.1 & 51.0 & 73.9 & 30.5 & 42.4 & 41.9 & 41.4 \\
\hline $\begin{array}{l}\text { Roofing } \\
\text { sheets }\end{array}$ & - & - & - & 43.8 & 28.5 & 47.8 & - & - & - & 39.2 & 39.8 & 0.0 \\
\hline $\begin{array}{l}\text { Wine } \\
\text { spirits \& } \\
\text { distillers }\end{array}$ & - & - & - & 45.3 & 30.2 & - & - & - & - & 36.1 & 35.6 & 0.0 \\
\hline $\begin{array}{l}\text { Ave. cap. } \\
\text { utilisation } \\
\text { rates (\%) }\end{array}$ & $\mathbf{4 0 . 3}$ & $\mathbf{4 2 . 0}$ & $\mathbf{3 8 . 1}$ & $\mathbf{3 7 . 2}$ & $\mathbf{3 0 . 4}$ & $\mathbf{2 9 . 3}$ & $\mathbf{3 2 . 5}$ & $\mathbf{3 0 . 4}$ & $\mathbf{3 2 . 4}$ & $\mathbf{3 4 . 6}$ & $\mathbf{3 6 . 1}$ & $\mathbf{3 9 . 6}$ \\
\hline
\end{tabular}

\section{3}

\section{Investment and operating incentive structure in manufacturing}

The incentive structure put in place by government in Nigeria during the economic adjustment era can be broadly classified into the pre-1999 and post-1999 (democracy) incentives. According to Adenikinju (1996: 348-53), the incentive structures exist at two different levels, the macro and industrial sector level.

For the pre-1999 era, at the macro level, the local currency was subjected to massive devaluation as a means of altering relative prices in favour of local as against imported manufactures. Government had abolished the import licence system in order to enhance the access of firms to foreign exchange, and adopted various export promotion schemes, amongst other incentives granted. At the industrial sector or firm level, various incentives were granted to the manufacturing sector to enhance their productive capacity and hence the economy. Generally, these incentives included the reduction of the corporate income tax rate from 45 to 40 per cent, increasing the capital allowances for plants and machinery for the firms to reduce their tax burdens, promoting tax-free dividends for qualified entities, and instituting special tax incentives to encourage local research and development (R \& D). Government granted up to 140 per cent tax relief to firms in respect of research and development ( $R \& D)$ expenses in the development of raw materials. Numerous institutional support measures were put in place by the authorities through the creation of the Raw Materials Research and Development Council (RMRDC), Industrial Data Bank, Industrial Development Coordinating Committee (IDCC), Federal Institute of Industrial 
Research (FIIRO), Project Development Agency (PRODA) and Export Processing Zone (EPZ), among others. The Companies Act of 1968 was amended to the Companies and Allied Matters Decree (CAMD), of 1990 to facilitate easier company incorporation and registration and hence making the setting up of business in the country easier. Further measures that more specifically relate to firms producing for the export market include the following: (1) Firms were allowed to open and maintain domiciliary accounts to keep their export earnings in foreign currencies; (2) The Export Incentives Decree was promulgated with various incentives to enhance export promotion and (3) The Export Guarantee and Insurance Scheme was put in place to help the international competitiveness of local firms.

For the post-1999 era, as part of the efforts to provide an enabling environment that is conducive to the growth and development of industries, inflow of foreign direct investment, shielding of existing investments from unfair competition, and stimulation of the expansion of domestic production capacity, the government developed a package of incentives to revive the economy, accelerate growth and development and reduce poverty.

The incentives for the Industrial sector include:

Specific taxation/fiscal measures that have been drawn to provide for deductions and allowances in the determination of taxable income of manufacturing enterprises, for instance:

Pioneer status: This is a concession to pioneer companies located in economically disadvantaged areas, providing a tax holiday period of five to seven years. These industries must be considered by the government, to be beneficial to the country's economy and in the interest of the public. Companies that are involved in local raw material development; local value added; labour intensive processing; export oriented activities; in-plant training; are also qualified for additional concessions.

Tax relief for research and development $(R \& D)$ : Up to 120 per cent of expenses on R\&D are tax deductible provided that such $\mathrm{R} \& \mathrm{D}$ activities are carried out in Nigeria and are connected with businesses to which allowances are granted. The result of such research could be patented and protected in accordance with internationally accepted industrial property rights.

Local raw materials utilisation: A 30 per cent tax concession for five years is given to industries that attain minimum local raw materials utilisation as follows: - agro 80 per cent; agro allied 70 per cent; engineering 65 per cent; chemical 60 per cent; petro-chemical 70 per cent.

Labour intensive mode of production: A 15 per cent tax concession for five years is granted firms that fall within this category. The rate is graduated in such a way that an industry employing one thousand persons or more will enjoy 15 per cent tax concession; an industry employing one hundred will enjoy only 6 per cent, while those employing two hundred will enjoy 7 per cent, and so on.

Local value added: A 10 per cent tax concession for five years applies here. This applies essentially to engineering industries, while some finished imported products serve as inputs. This is aimed at encouraging local fabrication rather than the mere assembly of completely knocked down parts.

In-plant training: 2 per cent tax concession for five years, of the cost of the facilities for training.

Infrastructure: 20 per cent of the cost of providing basic infrastructures such as roads, water, electricity, where they do not exist, is tax deductible once and for all.

Investment in economically disadvantaged areas: 100 per cent tax holiday for seven years and additional 5 per cent depreciation over and above the initial capital depreciation.

Abolition of excise duty: All excise duties were abolished with effect from the 1st of January, 1999.

Import duty rebate: A 25 per cent import duty rebate was introduced in 1995 to ameliorate the adverse effect of inflation and to ensure increase in capacity utilisation in the manufacturing sector. 
Re-investment allowance: This incentive is given to manufacturing companies that incur capital expenditure for purposes of approved expansion of production capacity; modernisation of production facilities; diversification into related products. It is aimed at encouraging reinvestment of profits.

Further incentives include: Investment tax allowances; companies with turnover of less than N1 million are taxed at a low rate of 20 per cent for the first five years of operation if they are into manufacturing; dividends from companies in the manufacturing sector with a turnover of less than N100 million are tax-free for the first five years of their operation.

\section{4}

\section{Analytical framework}

Studies have shown that the lowering of tariff rates impinges positively on total factor productivity in the Nigerian Manufacturing sector [Adenikinju and Chete, 2002]. In determining the impact of incentives in the food-manufacturing sector on standard of living for the period under consideration, data on eight selected quoted companies in the food beverages sector of the Nigerian Stock Exchange were gathered. This comprised of Gross Earnings, Profit before Tax and Profit after Tax. The selected companies were:

\section{7up Bottling Company PLc}

2. Cadbury Plc

3. Flour Mills Nig Plc

4. Northern Nigeria Flour Mills Plc

5. Nestle Foods Plc

6. Nigerian Bottling Company Plc

7. Union Dicon Salt PLc

8. P.S Mandrides Plc.

The other quoted food manufacturing companies namely Beverages (WA) Plc, Ferdinand Oil Mills Plc, National Salt Company Nig Plc, Nigeria Tobacco Company Plc and Tate Industries Plc had either gone extinct, de-listed from the stock market or had insufficient data, hence their exclusion from the analysis.
Tables 3, 4 and 5 show the Turnover (Gross Earnings), Profit before Tax (PBT) and Cost of Production for the listed food-manufacturing firms while Table 6 shows production index and manufacturing employment data. The tables as well as the relevant graphical sketches are all attached as appendices.

In attempting to capture the impact of incentives on the activities of these firms, it is postulated that the direct effect of incentives on any manufacturing activity is the reduction in relative cost of production for any given output level. Hence, the higher the impact of government incentives on productive activity of these firms, the lower the value of the cost of production in relative terms, and the lower the incentive value, the higher the relative cost of production.

\section{Hence if $v_{i}=$ incentive amount to firm $\mathrm{i}$ for one unit of production. \\ $\mathrm{c}_{\mathrm{i}}=$ cost of production in firm $\mathrm{i}$ for one unit of production}

Then, on an a priori basis,

$\mathrm{v}_{\mathrm{i}}$ is inversely related to $\mathrm{c}_{\mathrm{i}}$,

$\Rightarrow v_{i} \sim 1 / c_{i}$

i.e. $v_{i}$ varies directly with the reciprocal of $c_{i}$.

This implies that at any point in time $t$, for the $\mathrm{i}^{\text {th }}$ firm, the value of the government incentive varies directly with the inverse of the cost of production, indicating that under a ceteris paribus condition, very high production costs indicate that a firm enjoys very little incentives in production. This probably translates to the generation of power, the provision of accessible roads, and other infrastructural needs, in addition to paying for all its services at market costs for given output levels.

Hence given $\mathrm{T}$ as the level of turnover or gross earnings, PBT as profit before tax and $\mathrm{C}$ as total cost of production in a given year, the proxy value for incentives would be $T_{t}$ multiplied by the reciprocal value of cost of production. This allows for a year-by-year comparison of incentives enjoyed by a firm in its productive activity. This implies that the proxy for manufacturing incentives would be given as:

$\mathrm{v}=\frac{\mathrm{T}}{\mathrm{C}}=\frac{\mathrm{T}}{\mathrm{T}-\mathrm{PBT}}$ where $\mathrm{C}=\mathrm{T}-\mathrm{PBT}$ 
Aside from this seemingly simplistic approach, the impact of incentives appear rather difficult to capture in the Nigerian economy due specifically to the country's poor data base, and multiplicity of tax incentives which appear rather uncoordinated in application as well as implementation. Policy reversals have been a recurring factor in the economy such that there is general uncertainty as to the likely duration of any given policy on the operation of any sector. The study has attempted to overcome this setback by evaluating the cost of production in firms at any point in time - as the product of any prevailing incentive structures. Secondly, in the circumstance, the use of turnover and profits appear satisfactory, in determining the degree of incentives a firm enjoys, given that benefits of the incentives are reflected therein with or without a price increase by the firms. Even in the presence of domestic inflationary conditions, in the economy, the cushion provided by the benefits of incentives is expected to moderate the urge by the firms to respond through increasing their prices. Also given that the firms are generally aware of the intentions of government in granting the incentives, they are less likely to resort to frivolous price increases.

In proceeding with the analysis, the following relevant variables are defined as follows:

$\begin{array}{ll}\text { FMPI }= & \begin{array}{l}\text { Food Manufacturing Produc- } \\ \text { tion Index }\end{array} \\ \text { INCTV } & \begin{array}{l}\text { Proxy for Government Incen- } \\ \text { tive in Food Manufacturing }\end{array} \\ = & \text { Composite Price Index, Food. } \\ \text { CPIF }= & \text { Composite Price Index, } \\ \text { CPIDTK } & \text { Drinks, Tobacco and Kola } \\ \text { CPIA }= & \text { Composite Price Index, All } \\ & \text { Items } \\ \text { FBTEMPL = } & \text { Employment in Food Manu- } \\ & \text { facturing }\end{array}$

Table 7 shows the data on the proxy for incentives (INCTV) as well as FMPI, CPIF, CPIDTK and CPIA. With the foregoing, three levels of analysis would be conducted for this study in determining the impact of incentives on living standards:
- Determination of the degree of correlation of incentives with the value of gross output in manufacturing. This implies determining the relationship of incentives with the index on manufacturing (i.e. between INCTV and FMPI).

- Determination of the degree of correlation between the level of incentives and the composite price indices (i.e. between INCTV and CPIF, CPIDTK \& CPIA respectively). This is to show how the price of manufactures responds to the reduction in the relative production cost of these food manufacturers.

- Determination of the degree of correlation between incentives and employment creation in manufacturing (i.e. between INCTV and FBTEMPL). This is to show how employment creation responds to the proxy for incentives.

The extent to which incentives correlate positively or otherwise with employment and the price level may be indicative of the extent to which the general public benefits from the incentives governments grant the manufacturers.

\section{Results and discussion}

The results of the correlation analysis at the three different levels between different pairs of the above variables are attached in the appendix. The discussion is as follows.

\section{Incentives and food production index}

The results indicate a weak, negative and insignificant correlation coefficient of -0.254 between the above two variables implying that the incentives to the sector does not positively correlate with the movement in the production index. This is suggestive that the growth in output in the sub-sector is not directly traceable to the incentives granted to the affected firms and therefore cannot be said to be beneficial to the public. 


\section{Incentives and price index}

The correlation coefficient between incentives and the three different price indices are also weak, negative and insignificant with the composite price index for all-items, showing the greatest response (of - 0.218 ) to the incentive in the food sector. The food composite price index had the next best relationship with the incentive variable which is indicative of some, though negligible, positive effect of the food manufacturing incentive on food prices. Generally, as stated earlier, the relationship is weak, negative and insignificant.

\section{Incentives and employment}

The relationship between the incentive level and employment in the food-manufacturing firms is positive, though insignificant with a correlation coefficient of 0.187 . To this extent, some welfare benefits might have accrued to society, though marginally, with the implementation of government incentive measures to the food-manufacturing sub-sector.

\section{5}

\section{Conclusion}

In this paper, we attempted to investigate the relationship between the numerous incentives granted to the manufacturing sector by government and output of the sector, as well as with the price level of manufactures and employment created in the sector. This is borne out of the fact that many have wondered whether these manufacturers actually 'consume' or totally appropriate government incentives to them or pass the benefits on to society in terms of lower factory-gate prices for manufactures and employment creation.

The study, which was largely handicapped by the paucity of official data on the key variables and relied on proxies in some instances, showed that there is a weak, negative and insignificant correlation between these incentives and manufacturing output as well as the composite price index. This tends to be in tandem with Nwokoma (2002) where industrial capacity utilisation is found to be negatively correlated to the price level, and supporting the viewpoint that the larger society does not really benefit from the incentives granted to manufacturing. In addition, the results obtained from the current study tend to support the assertion that government policy conflicts, the negative effect of environmental factors and infrastructural weaknesses tend to reduce the effectiveness of incentives. Government, most times take back the benefits of incentives through other countervailing policies. The gains from a reduction in tariffs on imported raw materials are often lost by an increase in tariffs charged by the National Electric Power Authority NEPA, for example, even in cases where electricity is available. Hence, policy consistency by government has to be pursued as one of the things to be done to ensure that incentives granted to the sector achieve their desired objectives. One of the implications of these findings is that where policy inconsistencies are addressed, government should establish bench mark expectations from the manufacturers in terms of employment expansions, reduction in factory-gate prices and other societal benefits, whenever special concessions are to be granted to the sector. This will help to ensure that both the manufacturers themselves and the larger society share the benefits of efforts to revive the manufacturing sector.

\section{Endnote}

The helpful comments of Professor S. Tomori, Department of Economics, University of Lagos on an earlier draft of this paper is hereby acknowledged. 


\section{Appendices}

\section{Table 3}

Turnover (gross earnings) ( $\left.\mathrm{N}^{\prime} \mathrm{m}\right)$

\begin{tabular}{|l|c|c|c|c|c|c|c|c|c|c|c|c|}
\hline & $\mathbf{1 9 9 0}$ & $\mathbf{1 9 9 1}$ & $\mathbf{1 9 9 2}$ & $\mathbf{1 9 9 3}$ & $\mathbf{1 9 9 4}$ & $\mathbf{1 9 9 5}$ & $\mathbf{1 9 9 6}$ & $\mathbf{1 9 9 7}$ & $\mathbf{1 9 9 8}$ & $\mathbf{1 9 9 9}$ & $\mathbf{2 0 0 0}$ & $\mathbf{2 0 0 1}$ \\
\hline Seven Up & 415 & 570 & $\mathbf{7 5 4}$ & $\mathbf{1 4 1 9}$ & $\mathbf{1 7 7 1}$ & $\mathbf{1 5 4 1}$ & 2622 & 3513 & 4851 & 5723 & 6760 & $6241^{*}$ \\
\hline Cadbury & 458 & 719 & 1166 & 1938 & 3065 & 6340 & 8276 & 6435 & 7660 & 8898 & 10144 & 13230 \\
\hline $\begin{array}{l}\text { Flour mills } \\
\text { nig. plc. }\end{array}$ & 365 & 451 & 1042 & 2982 & 5975 & 4509 & 13079 & 16712 & 21456 & 23736 & 30923 & 43307 \\
\hline $\begin{array}{l}\text { N. nig flour } \\
\text { mills plc. }\end{array}$ & 27.5 & 40.1 & 28 & 294 & 1003 & 531 & 1204 & 1775 & 1562 & 1954 & 2289 & 4211 \\
\hline $\begin{array}{l}\text { Nestle nig. } \\
\text { plc. }\end{array}$ & 434 & 609 & 1025 & 1774 & 2358 & 4458 & 6128 & 5104 & 6187 & 7725 & 10027 & 14147 \\
\hline $\begin{array}{l}\text { Nig. bottling } \\
\text { coy. }\end{array}$ & 1182 & 2351 & 4173 & 7290 & 11671 & 10902 & 17912 & 19964 & 19880 & 20333 & 20609 & 34944 \\
\hline $\begin{array}{l}\text { Union dicon } \\
\text { salt plc. }\end{array}$ & 142.1 & 377 & 603 & 1124 & 1769 & 2700 & 2826 & 2718 & 3056 & 2698 & 2455 & $2576 *$ \\
\hline $\begin{array}{l}\text { P.S. } \\
\text { mandrides }\end{array}$ & 34.6 & 28.5 & 44.0 & 44.0 & 30.0 & 102 & 165.3 & 423.4 & 278 & 88.5 & 171 & $130 *$ \\
\hline Total & 3058.2 & 5145.6 & 8835 & 16865 & 27642 & 31083 & 52212.3 & 56644.4 & 64930 & 71155.5 & 83378 & 109839 \\
\hline
\end{tabular}

*2-year moving average Source: Nigerian Stock Exchange Yearbook 1995, 2001

Table 4

Profit before tax. $\left(\mathrm{N}^{\prime} \mathrm{m}\right)$

\begin{tabular}{|l|c|c|c|c|c|c|c|c|c|c|c|c|}
\hline & $\mathbf{1 9 9 0}$ & $\mathbf{1 9 9 1}$ & $\mathbf{1 9 9 2}$ & $\mathbf{1 9 9 3}$ & $\mathbf{1 9 9 4}$ & $\mathbf{1 9 9 5}$ & $\mathbf{1 9 9 6}$ & $\mathbf{1 9 9 7}$ & $\mathbf{1 9 9 8}$ & $\mathbf{1 9 9 9}$ & $\mathbf{2 0 0 0}$ & $\mathbf{2 0 0 1}$ \\
\hline Seven Up & 23 & 27 & 35 & 49 & 58 & 62 & 90.2 & 172 & 301 & 353 & 429 & $391^{*}$ \\
\hline Cadbury & 37 & 103 & 183 & 360 & 611 & 1001 & 1219 & 941 & 1010 & 1237 & 1637 & 2406 \\
\hline $\begin{array}{l}\text { Flour mills } \\
\text { nig. plc. }\end{array}$ & 10.6 & 18.8 & 42 & 356 & 462 & 498 & 618 & 1002 & 684 & 775 & 677 & 2266 \\
\hline $\begin{array}{l}\text { N. nig. flour } \\
\text { mills plc. }\end{array}$ & $(5.8)$ & 2.8 & 5.87 & 81.5 & 100.7 & 122 & 58 & 142 & 101 & 88 & 83 & 221 \\
\hline $\begin{array}{l}\text { Nestle nig. } \\
\text { plc. }\end{array}$ & 65.9 & 98 & 144 & 302 & 371 & 838 & 1610 & 816 & 878 & 1617 & 2225 & 3699 \\
\hline $\begin{array}{l}\text { Nig. bottling } \\
\text { coy. }\end{array}$ & 108 & 240 & 434 & 860 & 1120 & 1233 & 1856 & 2001 & 1981 & $(425)$ & 945 & 4170 \\
\hline $\begin{array}{l}\text { Union dicon } \\
\text { salt plc. }\end{array}$ & 41 & 74 & 141 & 348 & 498 & 410 & 363 & 325 & 325 & 278 & 244 & $261^{*}$ \\
\hline \begin{tabular}{l} 
P.S. mandrides \\
\hline
\end{tabular} & 0.30 & 2.5 & 6.8 & 4.4 & 5.0 & 13.8 & 34.8 & 45.3 & 14.0 & 14.7 & 27 & $20.85^{*}$ \\
\hline
\end{tabular}

* 2-year moving average Source: Nigerian Stock Exchange Yearbook 1995, 2001 
Table 5

Costs of production (turnover less profit before tax)

\begin{tabular}{|c|c|c|c|c|c|c|c|c|c|c|}
\hline ธิ్ & 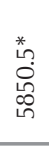 & 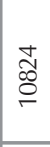 & 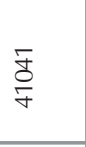 & \& & $\underset{+}{\stackrel{ᄋ}{0}}$ & $\begin{array}{l}\stackrel{+}{\hat{D}} \\
\text { 品 }\end{array}$ & 䀝 & 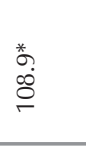 & $\begin{array}{l}\hat{2} \\
\hat{o} \\
\sigma\end{array}$ & 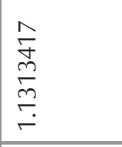 \\
\hline ఫ્రి & $\overline{\widetilde{\sigma}}$ & $\begin{array}{l}0 \\
\stackrel{0}{\circ} \\
\infty\end{array}$ & $\begin{array}{l}\text { I্t } \\
\text { D্ }\end{array}$ & 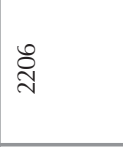 & ర్ & $\begin{array}{l}\underset{d}{\mathbb{N}} \\
\stackrel{\sim}{N}\end{array}$ & $\overline{\bar{ন}}$ & $\underset{\sim}{\exists}$ & 衣竞 & 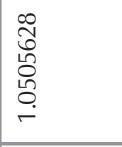 \\
\hline Б્ & 옷 & $\bar{g}$ & $\begin{array}{l}\bar{\Xi} \\
\text { సิ }\end{array}$ & $\begin{array}{l}\stackrel{0}{\circ} \\
\stackrel{\circ}{\circ}\end{array}$ & $\frac{\infty}{6}$ & 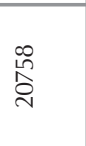 & 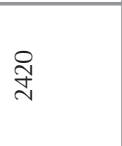 & $\stackrel{\infty}{x}$ & 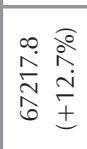 & 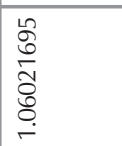 \\
\hline$\stackrel{2}{\mathscr{2}}$ & 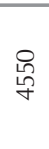 & 융 & 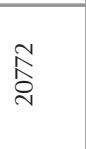 & $\underset{f}{\sigma}$ & 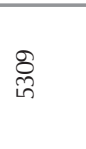 & 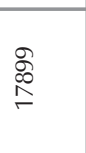 & $\underset{\curvearrowright}{\stackrel{\sim}{N}}$ & $\hat{\ddot{D}}$ & 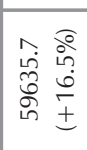 & $\begin{array}{l}\circ \\
\infty \\
\infty \\
\varnothing \\
8 \\
0\end{array}$ \\
\hline Sे & $\underset{\text { F }}{\bar{f}}$ & 㕝 & $\stackrel{0}{\frac{0}{\hbar}}$ & $\underset{\widetilde{\zeta}}{\tilde{\sigma}}$ & 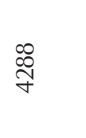 & $\begin{array}{l}\overparen{ֶ} \\
\stackrel{2}{\curvearrowright}\end{array}$ & ๙ิ & $\underset{\infty}{\infty}$ & 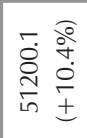 & 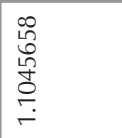 \\
\hline § & 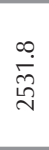 & $\hat{R}$ & 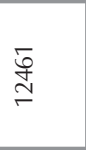 & $\stackrel{\stackrel{f}{\leftarrow}}{\leftarrow}$ & $\stackrel{\infty}{\frac{\infty}{5}}$ & $\begin{array}{l}\overbrace{0}^{\circ} \\
\stackrel{్}{0}\end{array}$ & $\stackrel{\Re}{\sim}$ & $\begin{array}{l}\stackrel{2}{0} \\
\stackrel{m}{r}\end{array}$ & 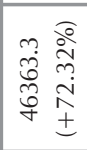 & 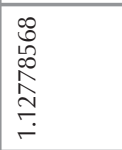 \\
\hline 关 & $\underset{\mathscr{\vartheta}}{\mathscr{f}}$ & ڤิ & $\bar{q}$ & के & 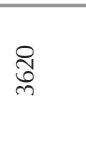 & 。요 & ஓి & $\begin{array}{c} \\
\substack{0 \\
\infty \\
\infty} \\
\infty\end{array}$ & 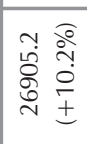 & 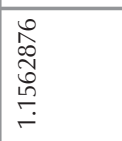 \\
\hline す̆ & $\stackrel{m}{\stackrel{2}{\leftarrow}}$ & 志 & $\sum_{i n h}^{m}$ & 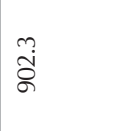 & $\begin{array}{l}\stackrel{\leftrightarrow}{\circ} \\
\stackrel{\sigma}{\circ}\end{array}$ & $\begin{array}{l}\bar{\Sigma} \\
\stackrel{8}{\circ}\end{array}$ & 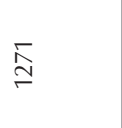 & $\stackrel{\llcorner}{\sim}$ & 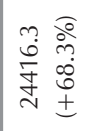 & 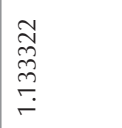 \\
\hline$\widetilde{\sigma}$ & $\stackrel{?}{\stackrel{P}{r}}$ & $\begin{array}{l}\infty \\
\stackrel{\infty}{n} \\
⺊\end{array}$ & ర్ర్ర & $\stackrel{\stackrel{L}{\mathrm{~N}}}{\stackrel{\sim}{v}}$ & $\underset{\sim}{\stackrel{N}{f}}$ & ণ্ণু & $\stackrel{゚}{R}$ & $\stackrel{\text { : }}{\dot{m}}$ & 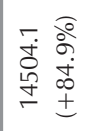 & 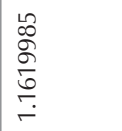 \\
\hline$\tilde{\sigma}$ & $\frac{\Omega}{R}$ & $\dddot{\circ}$ & $\underset{\square}{8}$ & $\frac{\tilde{\sigma}}{\grave{N}}$ & $\bar{\infty}$ & 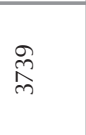 & ర్f & $\stackrel{N}{N}$ & 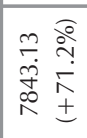 & 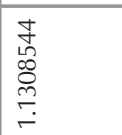 \\
\hline Бे & 学 & $\frac{6}{6}$ & 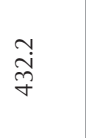 & $\stackrel{m}{m}$ & $\bar{E}$ & $\bar{\Sigma}$ & ల్లి & $\stackrel{\sim}{N}$ & 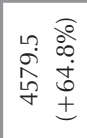 & 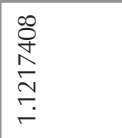 \\
\hline \&్ & శ్లి & $\bar{q}$ & 守 & $\stackrel{m}{m}$ & $\bar{o}$ & 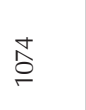 & $\stackrel{\check{\sigma}}{\circ}$ & $\stackrel{m}{m}$ & 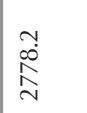 & $\begin{array}{l}\infty \\
\infty \\
0 \\
0 \\
0\end{array}$ \\
\hline & 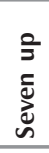 & 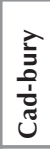 & 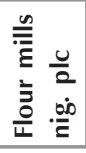 & 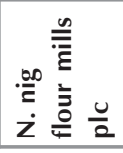 & 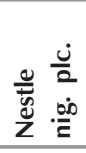 & 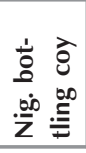 & 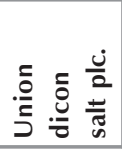 & 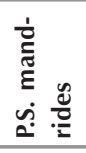 & 氞 & 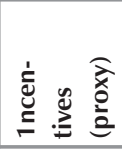 \\
\hline
\end{tabular}




\section{Table 6}

Manufacturing production index and employment

\begin{tabular}{|l|c|c|c|c|c|c|c|c|c|c|c|c|}
\hline & $\mathbf{1 9 9 0}$ & $\mathbf{1 9 9 1}$ & $\mathbf{1 9 9 2}$ & $\mathbf{1 9 9 3}$ & $\mathbf{1 9 9 4}$ & $\mathbf{1 9 9 5}$ & $\mathbf{1 9 9 6}$ & $\mathbf{1 9 9 7}$ & $\mathbf{1 9 9 8}$ & $\mathbf{1 9 9 9}$ & $\mathbf{2 0 0 0}$ & $\mathbf{2 0 0 1}$ \\
\hline $\begin{array}{l}\text { Index of } \\
\text { manufacturing } \\
\text { production* } \\
\text { (food) } \\
\text { (1985=100) }\end{array}$ & 229 & 186.3 & 147 & 147 & 127.5 & 106.3 & 111.9 & 106.6 & 109.3 & 113.1 & 113.4 & 124.75 \\
\hline $\begin{array}{l}\text { Manufacturing } \\
\text { employment } \\
- \text { total ('000) }\end{array}$ & 340.1 & ++340.1 & 271.3 & +305.7 & +288.5 & 241.1 & +264.8 & 211.6 & 191.8 & +201.7 & +196.75 & +199.225 \\
\hline $\begin{array}{l}\text { Manufacturing } \\
\text { employment } \\
- \text { food/bev/ } \\
\text { tob (8\% of } \\
\text { total) }\end{array}$ & 27.208 & 27.208 & 21.704 & 24.456 & 23.08 & 19.288 & 21.184 & 16.928 & 15.344 & 16.136 & 15.74 & 15.938 \\
\hline
\end{tabular}

Source: Computed from CBN Annual reports (various)

* This is the average of the index of manufacturing production in sugar confectionary and soft drinks approximated as the index of food manufacturing production.

++ The 1990 value is assumed for 1991, in the absence of reliable data

$+\quad$ This represents 2-year moving averages

\section{Table 7}

Data on incentive proxy and price index and employment variables

\begin{tabular}{|l|c|c|c|c|c|c|}
\hline & $\begin{array}{c}\text { FMPI } \\
(\mathbf{1 9 8 5}=\mathbf{1 0 0})\end{array}$ & INCTV & $\begin{array}{c}\text { CPIF } \\
(\mathbf{1 9 8 5}=\mathbf{1 0 0})\end{array}$ & $\begin{array}{c}\text { CPIDTK } \\
(\mathbf{1 9 8 5}=\mathbf{1 0 0})\end{array}$ & $\begin{array}{c}\text { CPIA } \\
\mathbf{( 1 9 8 5 = 1 0 0 )}\end{array}$ & FBTEMPL \\
\hline $\mathbf{1 9 9 0}$ & 229.00 & 1.04 & 308.00 & 267.40 & 293.20 & 27.208 \\
\hline $\mathbf{1 9 9 1}$ & 186.30 & 1.12 & 345.90 & 305.30 & 330.90 & 27.208 \\
\hline $\mathbf{1 9 9 2}$ & 147.00 & 1.13 & 506.80 & 460.20 & 478.40 & 21.704 \\
\hline $\mathbf{1 9 9 3}$ & 147.00 & 1.16 & 800.20 & 693.20 & 751.90 & 24.456 \\
\hline $\mathbf{1 9 9 4}$ & 127.50 & 1.13 & 1174.60 & 1195.40 & 1180.70 & 23.08 \\
\hline $\mathbf{1 9 9 5}$ & 106.30 & 1.16 & 2017.70 & 1973.20 & 2040.40 & 19.288 \\
\hline $\mathbf{1 9 9 6}$ & 111.90 & 1.13 & 2646.70 & 2467.60 & 2661.10 & 21.184 \\
\hline $\mathbf{1 9 9 7}$ & 106.60 & 1.10 & 2864.20 & 2640.60 & 2863.20 & 16.928 \\
\hline $\mathbf{1 9 9 8}$ & 109.30 & 1.09 & 3044.40 & 2762.60 & 3149.20 & 15.344 \\
\hline $\mathbf{1 9 9 9}$ & 113.10 & 1.06 & 2995.50 & 2914.50 & 3273.30 & 16.136 \\
\hline $\mathbf{2 0 0 0}$ & 113.40 & 1.05 & 3213.80 & 3341.10 & 3785.70 & 15.74 \\
\hline $\mathbf{2 0 0 1}$ & 124.75 & 1.13 & 4257.8 & 4813.9 & 4458 & 15.938 \\
\hline
\end{tabular}

Source: Central Bank of Nigeria Statistical Bulletin, 2001 and Annual Report 2002, as well as computations. 


\section{Correlation results}

\begin{tabular}{|ll|c|c|}
\hline & & FMPI & INCTV \\
\hline \multirow{2}{*}{ FMPI } & Pearson Correlation & 1.000 & -0.254 \\
& Sig. (2- tailed) &. & 0.426 \\
& $\mathrm{~N}$ & 12 & 12 \\
\hline \multirow{2}{*}{ INCTV } & Pearson Correlation & -0.254 & 1.000 \\
& Sig. (2- tailed) & 0.426 & $\cdot$ \\
& $\mathrm{N}$ & 12 & 12 \\
\hline
\end{tabular}

\begin{tabular}{|ll|c|c|}
\hline & & INCTV & CPIA \\
\hline INCTV & Pearson Correlation & 1.000 & -0.218 \\
& Sig. (2- tailed) &. & 0.496 \\
& N & 12 & 12 \\
\hline CPIA & Pearson Correlation & -0.218 & 1.000 \\
& Sig. (2- tailed) & 0.496 &. \\
& N & 12 & 12 \\
\hline
\end{tabular}

\begin{tabular}{|ll|c|c|}
\hline & & INCTV & CPIF \\
\hline \multirow{4}{*}{ INCTV } & Pearson Correlation & 1.000 & -0.162 \\
& Sig. (2- tailed) &. & 0.614 \\
& $\mathrm{~N}$ & 12 & 12 \\
\hline \multirow{2}{*}{ CPIF } & Pearson Correlation & -0.162 & 1.000 \\
& Sig. (2- tailed) & 0.614 &. \\
& $\mathrm{~N}$ & 12 & 12 \\
\hline
\end{tabular}

\begin{tabular}{|cl|c|c|}
\hline & & INCTV & FBTEMPL \\
\hline INCTV & Pearson Correlation & 1.000 & 0.187 \\
& Sig. (2- tailed) &. & 0.560 \\
N & 12 & 12 \\
\hline FBTEMPL Pearson Correlation & 0.187 & 1.000 \\
& Sig. (2- tailed) & 0.560 &. \\
N & 12 & 12 \\
\hline
\end{tabular}

\begin{tabular}{|ll|c|c|}
\hline & & INCTV & CPIDTK \\
\hline \multirow{2}{*}{ INCTV } & Pearson Correlation & 1.000 & -0.144 \\
& Sig. (2- tailed) &. & 0.655 \\
& $\mathrm{~N}$ & 12 & 12 \\
\hline CPIDTK & Pearson Correlation & -0.144 & 1.000 \\
& Sig. (2- tailed) & 0.655 &. \\
& $\mathrm{~N}$ & 12 & 12 \\
\hline
\end{tabular}

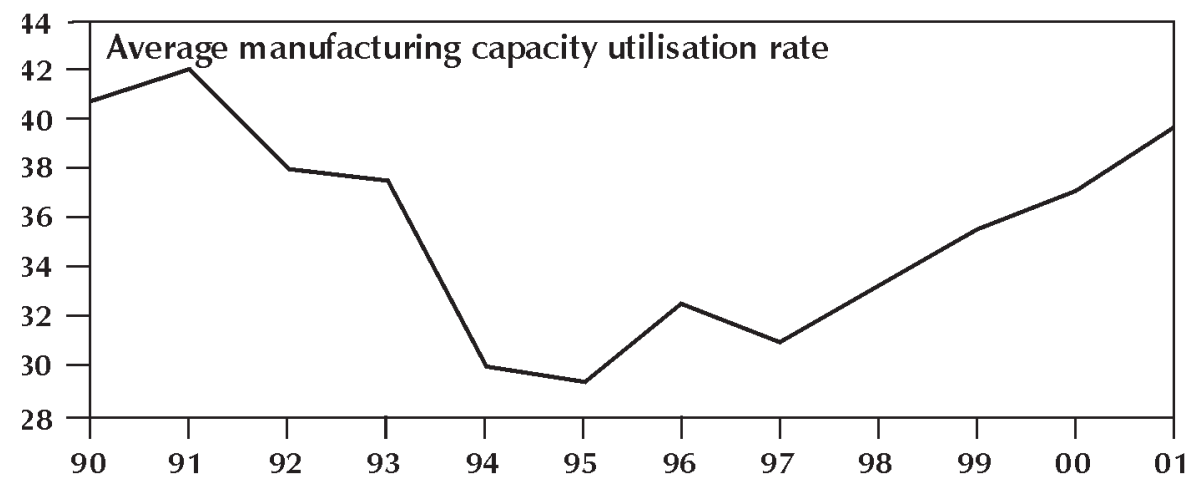

-Avecaputilstn

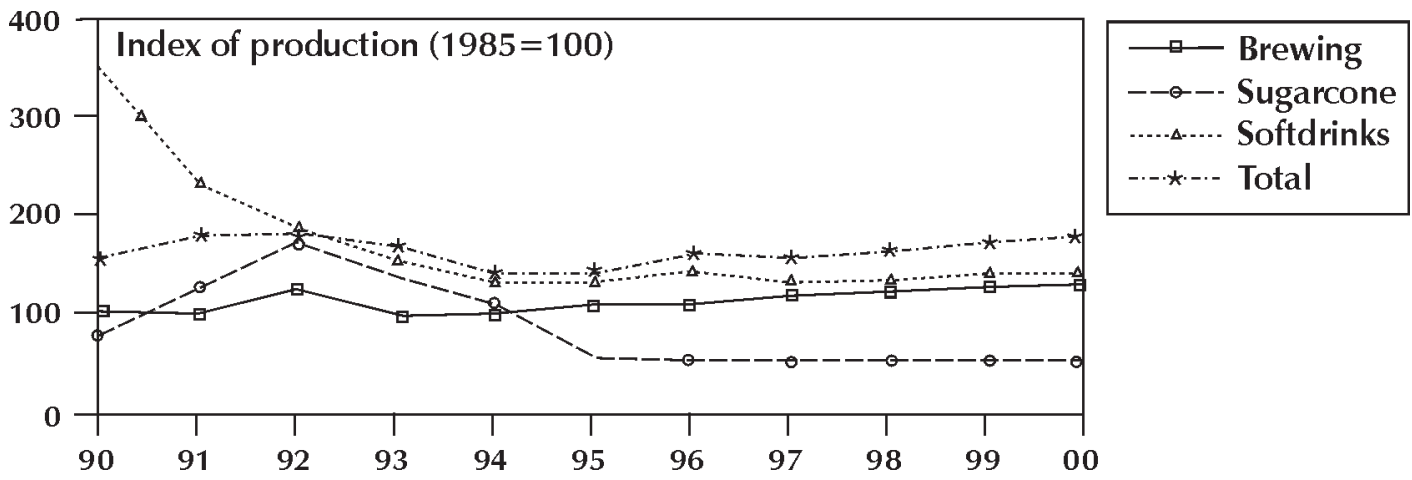


Index of industrial production - by sub sectors
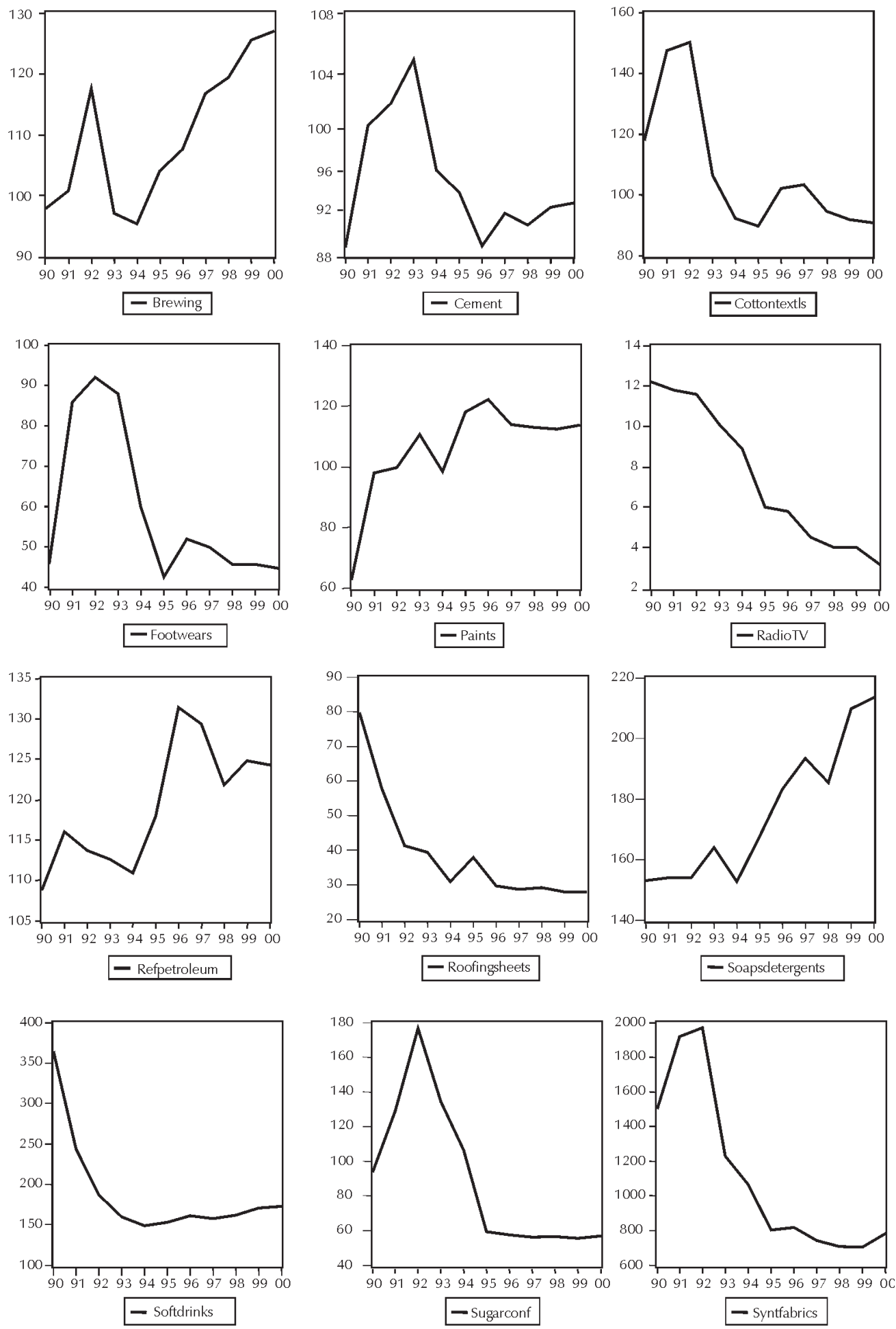

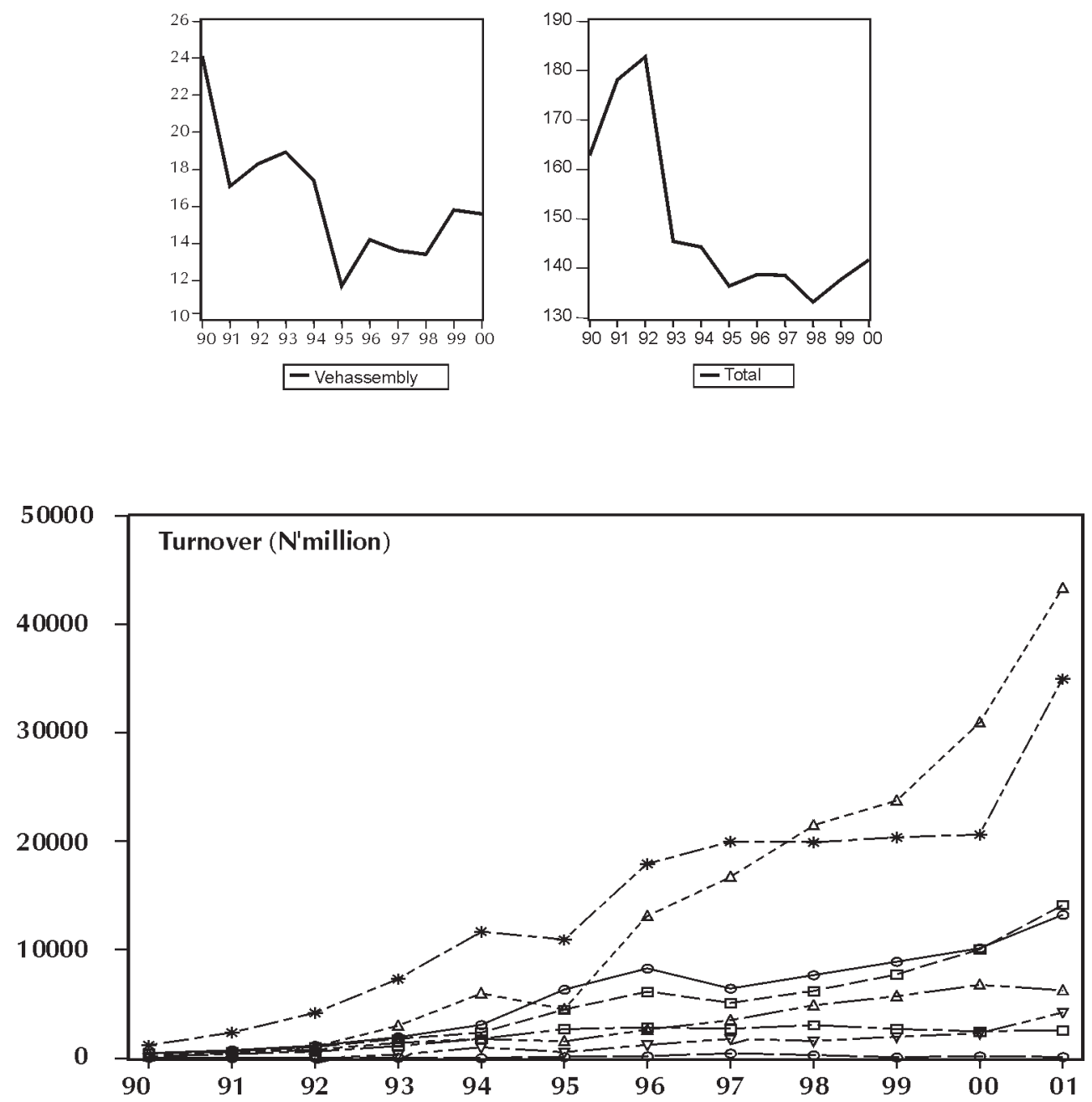

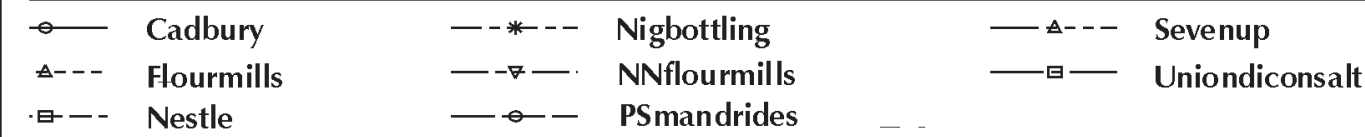



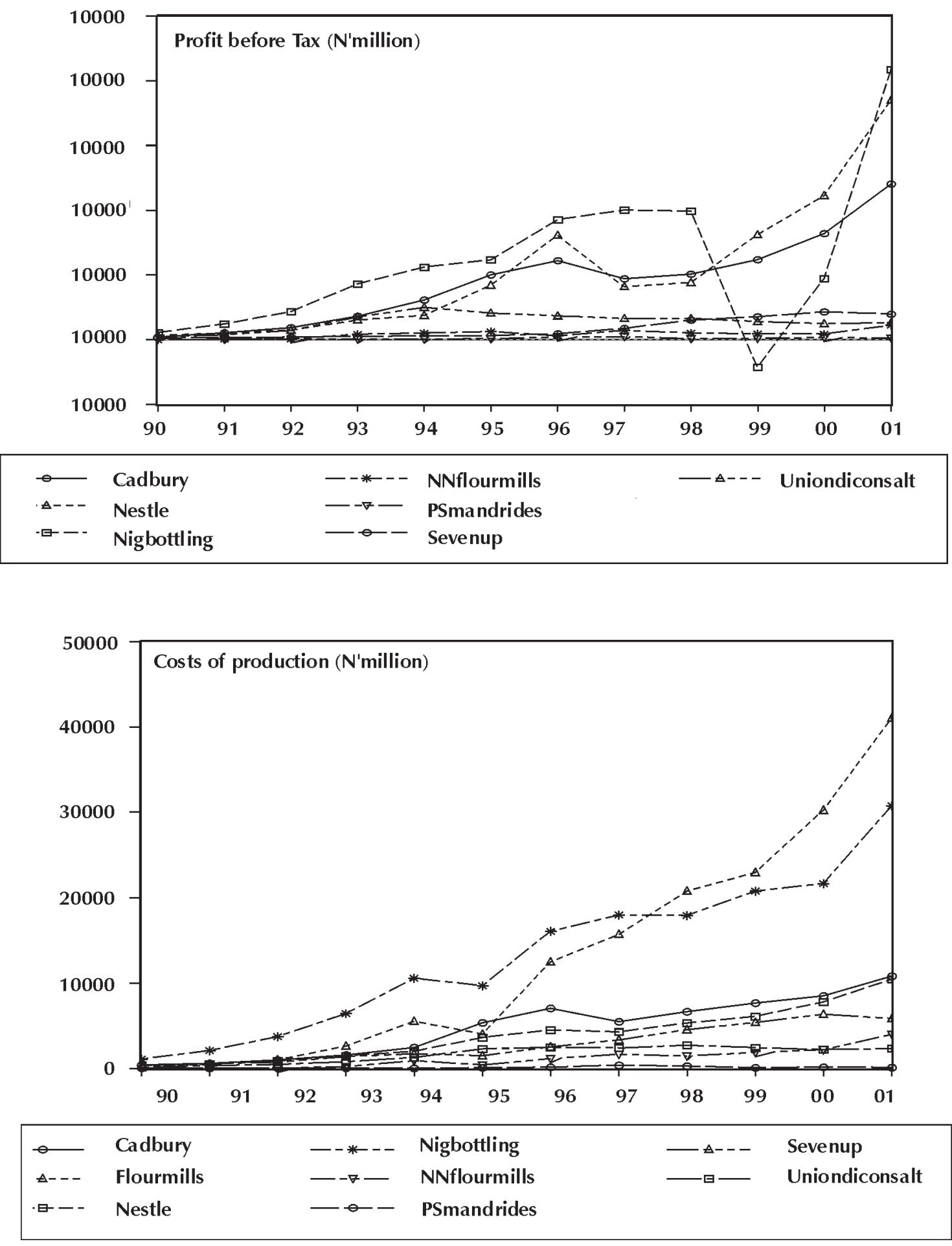

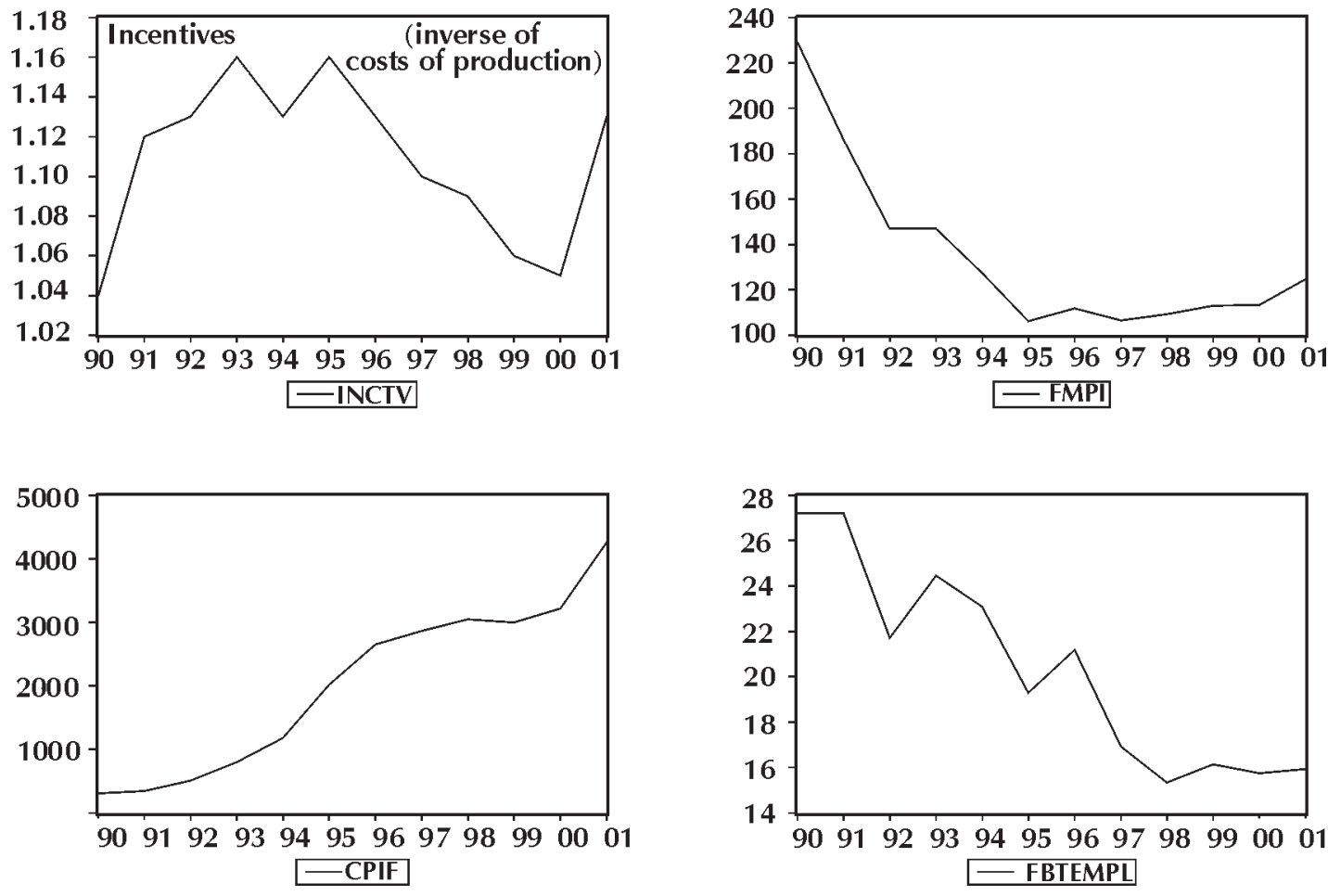

\section{References}

1 ADENIKINJU, A. (1996) "Structural adjustment programme and productive efficiency in the Nigerian manufacturing sector: Lessons beyond adjustment in beyond adjustment: management of the Nigerian economy", Selected Papers of the 1996 Annual Conference of the Nigerian Economic, Society.

2 ADENIKINJU, A.F. \& CHETE, L.N. (2002) "Productivity, market structure and trade liberalisation in Nigeria", AERC Research Paper, 126, November, African Economic Research Consortium, Nairobi.

3 AGBELOGODE, E.N. (1999) "Effects of petroleum products scarcity on capacityutilisation of selected companies in Lagos", Unpublished MBA Dissertation Department of Business Administration, Enugu State University of Science and Technology.

4 AKINLO E.A. (1996) "Improving the performance of the Nigerian manufacturing subsector after adjustment; selected issues and proposals", Nigerian Journal of Economic and Social Studies, 2(July).
5 CENTRAL BANK OF NIGERIA (2001)

Statistical Bulletin, 12(December).

6 FEDERAL OFFICE OF STATISTICS Annual Digest of Statistics.

7 LOTO, M.A. (2001) "The impact of manufacturing activities on economic development process", Paper presented at Staff Seminar, Department of Economics, University of Lagos

8 NDIULOR, A.O. (1999) "An appraisal of accounts receivables in nigerian companies in the economic adjustment era", Unpublished MBA Dissertation, Department of Banking and Finance, Enugu State University of Science and Technology.

9 NIGERIAN STOCK EXCHANGE (1995, 2001 and 2002) Factbook.

10 NWOKOMA, N.I. (2002), "Performance of the manufacturing sector and impact on living standards in Nigeria”, First Bank of Nigeria Plc. Quarterly Review, 02(02).

11 OLAYIDE, S.O. (1976) Economic Survey of Nigeria (1960-1975) Aromolaran Publishing Co. Limited: Ibadan. 